\section{En fyldig og god kasuistikkbok}

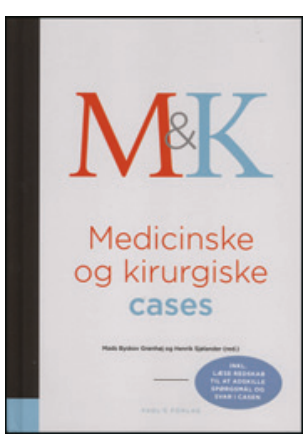

Mads Byskov Grønhøj, Henrik Sjølander, red. Medicinske og kirurgiske cases

932 s, tab, ill. København: FADL's Forlag, 2014. Pris DKK 800

ISBN 978-87-7749-755-1

Denne utgivelsen henvender seg primært til medisinstudenter. Boken er en stor samling av kliniske kasuistikker innenfor en rekke medisinske og kirurgiske fag. Den er således ment å være relevant supplerende litteratur for trening i klinisk og differensialdiagnostisk tankegang, snarere enn en lærebok i indremedisin og kirurgi.

Boken er inndelt i 19 kapitler, med hvert sitt fagfelt. Følgende fag er inkludert: infeksjonssykdommer, gastroenterologi og gastrokirurgi, lungemedisin, kardiologi og hjerte- og karkirurgi, nefrologi, endokrinologi, hematologi, revmatologi, geriatri, nevrologi og nevrokirurgi, pediatri, akuttmedisin, urologi, gynekologi og obstetrikk, ortopedi, øre-nese-hals-sykdommer og oftalmologi.

Språket er enkelt, og kasuistikkene følger en fast mal uavhengig av fagfelt. I tillegg til kasuistikkene finnes det mange små faktabokser som utdyper og/eller forklarer viktige kliniske poeng. Flere steder er det også tabeller og algoritmer som gir kortfattet oversikt over for eksempel differensialdiagnostisk tankegang ved ulike symptompresentasjoner, ulike kliniske skåringsskjemaer osv. Boken har et godt register, og den er dermed enkel å finne frem i dersom man for eksempel vil repetere diagnostikk og behandling av en spesifikk sykdom. Kasuistikkenes oppbygning oppleves god. Helt fra anamnese til behandling og plan for videre oppfølging blir man tvunget til å ta valg og gjøre vurderinger.

Bokens struktur er nokså lik flere av de engelskspråklige kasuistikkbøkene. Kanskje vil noen påpeke at prisen er i overkant stiv sammenliknet med de engelskspråklige alternativene. Her må man likevel ta med i betraktningen at boken både har flere kasuistikker og dekker over flere fagområder enn de fleste konkurrentene. Et annet pluss er at det benyttes samme måleenheter for blodprøver som i Norge, med unntak av hemoglobin (som måles i mmol/l). Boken er oppdatert etter de nyeste danske retningslinjene, men ettersom behandlingstradisjon kan variere noe fra land til land, bør man likevel sjekke behandling og diagnostikk opp mot norske retningslinjer hvis man er i tvil. Medicinske og kirurgiske cases kan anbefales til alle medisinstudenter som går på kliniske semestre. Spesielt siste års studenter burde ha god nytte av denne boken i sine forberedelser til avsluttende eksamener.

\section{Appen jeg ikke visste jeg trengte}

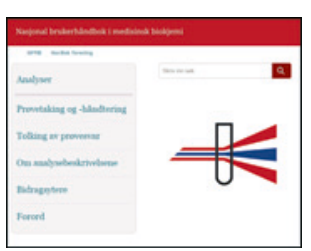

Tor-Arne Hagve, red.

Nasjonal brukerhåndbok i medisinsk biokjemi

App. Lastes ned fra App Store eller fra Google Play. Pris Gratis

Nasjonal brukerhåndbok i medisinsk biokjemi har kommet i 4. utgave, og foreløpig foreligger den kun elektronisk. Den finnes som gratis applikasjon, eller «app», til iOS- og Android-telefoner, og det er denne versjonen undertegnede har testet $\mathrm{i}$ to måneder. I denne perioden har jeg jobbet som fastlegevikar og legevaktslege.

Det foreligger et vell av medisinske apper, og min første tanke rundt denne var: Vil jeg noen gang bruke den? Jeg bestiller tross alt som oftest de blodprøvene jeg vet både indikasjonen for og tolkningen av. Jeg må vel innrømme at tidligere papirutgaver av denne ressursen er noe jeg sjelden har brukt. Noe motvillig slo jeg derfor opp noen prøver for første gang i starten av januar. Å slå opp gikk overraskende greit. Designen er intuitiv og ujålete, og man trenger ingen opplæring i bruken av den. Søkefunksjonen er også god med fortløpende forslag til fullstendige søkeord.

Å slå opp prøver er appens store styrke. Man får raskt god og sentral informasjon om prøvene. Denne informasjonen er delt opp i bl.a. bakgrunn, indikasjoner, prøvetakingsrutiner, referanseområder og tolkning. Jeg synes dette fungerer godt, og man leser seg raskt opp på god og relevant informasjon.

Snart fant jeg ut at man også kan søke på sykdomstilstander. Man søker på tilstanden, og relevante prøver dukker opp. Dessverre fungerer ikke søkefunksjonen her spesielt godt, og treffene er ikke alltid hva jeg håper på. Da jeg for eksempel søkte på binyrebarksvikt, fikk jeg to treff: 21-hydroksylase-antistoff (aldri hørt om, men det gjør ikke noe, for jeg kan raskt lese meg opp i appen) og aldosteron. Jeg fikk overraskende nok ikke opp for eksempel kortisol. Dette er nok fordi prøvene kun kommer opp om sykdomstilstanden er nevnt under den aktuelle prøven. Da jeg slo opp på kortisol, hadde man nemlig brukt ordet binyrebarkinsuffisiens. Jeg mener at appen har et klart forbedringspotensial om søkefunksjonen bedres fra sykdomstilstander til prøver.

Etter hvert merket jeg at jeg - oftere enn jeg trodde - hadde behov for å slå opp prøver. Kan fedme forklare denne lett økte gamma-GT-verdien? Hva er referanseområdet for totalkolesterol hos en 70 år gammel mann? Det er her appen er best, og det er vel også for dette den hovedsakelig er ment. Det var også tilfredsstillende at jeg kunne være trygg i en diskusjon med en biokjemiker på Rikshospitalet vedrørende prøvetakingsrutiner på kromogranin A. Det er jeg ikke vant til.

Jeg visste ikke at jeg hadde behov for denne appen, men det har jeg. Den er derfor nå fast inventar på min telefon.

Eirik Methlie Hagen

Fastlegevikar, Oslo 